\title{
The Circum-Pacific Council for Energy and Mineral Resources (CPCEMR)
}

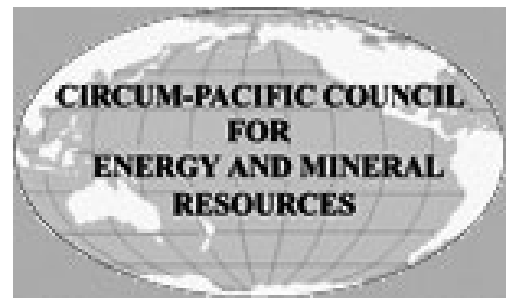

\section{http://www.circum-pacificcouncil.org}

\begin{abstract}
About the CPCEMR
\section{Our beginning}

The Council was founded in 1972 under the leadership of Michel T. Halbouty, who saw the need for better international communication and scientific exchange about the geology and the energy and mineral resources of the Pacific Basin and surrounding land areas. The Circum-Pacific Council was organized as an international, taxexempt association of earth scientists and engineers who represent industry, academia, and government.
\end{abstract}

\section{Our history}

Over the past quarter century, the Council has sponsored five Pacific-wide conferences, six regional symposia and over twenty workshops around the Pacific; compiled and published 51 geoscience and resource maps with accompanying explanatory booklets; and organized two international geospatial data projects for East Asia and the entire Pacific Rim. The Circum-Pacific Map Project has compiled geologic and resource data, including geohazard and environmental information. The principal objective of these syntheses of earth science information is to foster scientific interchange across the Pacific Basin and surrounding areas. The Council is now striving to bring this information to a wider public beyond the technical community.

\section{What we do}

The mission of the Council is to engender better understanding and communication about earth resources and understanding risk in the Pacific region. The Council's goals include: improving knowledge of earth resources and damaging natural hazards in the Pacific Region; increasing collaboration among geologists, hydrologists, biologists, oceanographers, and related scientists; and disseminating earth science information through maps, publications, symposia and workshops.

\section{How we operate}

The council operates under an international Board of Directors to promote partnerships and to organize regional panels and working groups of experts to compile, integrate, analyze, and disseminate earth science information. These activities have involved the participation of more than 200 national and international organizations and more than 40 countries. Leading scientists, their colleagues and students are encouraged to participate in Council activities. The Council seeks to work with organizations that share our scientific goals.

\section{Symposia and workshops}

After the First Circum-Pacific Conference in 1974, the Council decided to sponsor similar Pacific-wide conferences every four years. Successful conferences were held in Honolulu, Hawaii in 1974, 1978, 1982, and in Singapore in 1986. In addition to volunteer papers on current earth science research, these conferences included meetings of Council Officers, Directors, and representatives of cooperating organizations, along with displays of the Map Project and other Council-sponsored projects. Transactions and proceedings volumes were published after each conference. By 1990 the Council elected to concentrate its efforts on convening smaller symposia and workshops, as these began to be more productive.

The CPCEMR sponsored symposia and workshops are intended to assist countries by providing a forum for in-depth discussions on topics germane to their needs. Framework geology has been the key to understanding hydrocarbon and mineral resources as well as potential risk from natural hazards. More recent workshops have begun to analyze the demand side of resources, particularly as it relates to sustainable development. Listed here are typical symposia subjects with year and place of meetings:

2004, Seattle, USA, "Dealing with Natural Calamities around the
Pacific Rim" 2002, Hanzhou, China, "Chinese Petroleum Exploration in the 21 st Century"

2001, Stanford University, California, U.S.A. "Crowding the Rim: Fostering Collaborative Solutions for Regional Risk"

1994, Hanoi, Vietnam, "Geology, Exploration and Development Potential of Energy and Mineral Resources of Vietnam and Adjoining Regions”

1993, Nanjing, China, "International Basin Tectonics and Hydrocarbon Accumulation"

1992, Bangkok, Thailand, "Energy and Mineral Resources in the Circum-Pacific Region and the Environmental Impact of their Utilization"

1989, San Jose, Cost Rica, "Energy and Mineral Potential of the Central America-Caribbean Region"

1989, Khabarovsk, Russia, "Tectonics, Energy and Mineral Resources of the Northwest Pacific"

1985, Santiago, Chile, "Geology of the Andes and its Relation to Hydrocarbons and Mineral Resources"

1984, Hilo, Hawaii,USA., "Pacific Volcanology: Forecasting Eruptions and Mitigating their Effects"

1984-1985, Antarctica and Beyond, "Pole to Pole Operation Deep Sweep"

1981, Stanford University, California, USA, "Tectonostratigraphic Terranes of the Circum-Pacific Region"

\section{Publications}

The Earth Science Series of books published by the Circum-Pacific Council began in 1985. It was designed, specifically, to publish papers that include new data and maps; report on CPCEMR sponsored conferences, symposia and workshops and describes the results of onshore and marine geological and geophysical research and explorations in and around the Pacific Basin. Topics of interest include framework geology, petroleum geology, hard minerals, geothermal energy, environmental geology, volcanology, oceanography, tectonics, geophysics, geochemistry, and applications of renewable energy.

There are a total of 16 volumes in the Earth Science Series. They include:

\footnotetext{
- Tectonostratigraphic Terranes of the Circum-Pacific Region
} 
- The Antarctic Continental Margin: Geology and Geophysics of Offshore Wilkes Land

- The Antarctic Continental Margin: Geology and Geophysics of the Western Ross Sea

- Geology and Resource Potential of the Continental Margin of Sea to Baja California

- Marine Geology, Geophysics, and Geochemistry of the Woodlark Basin-Solomon Islands

- Geology of the Andes and Its Relation to Hydrocarbon and Mineral Resources

- Basin Formation, Ridge Crest Processes, and Metallogenesis in the North Fiji Basin

- Energy and Mineral Potential of the Central AmericanCaribbean Region

CPCEMR products are now being published in both digital and print form by cooperating organizations engaged in specific topics. Several recent examples include:

HAZPAC - an interactive digital database characterizing the Hazards of the Pacific, published by the U.S. Geological Survey, Digital Data Series DDS-76, 2002

Crowding the Rim; Global Consequences of Natural Hazards - an educational module on natural hazards and risk, published by Stanford University (http://spice.stanford.edu)

Digital geotectonic maps of East and Southeast Asia, published by the Geological Survey of Japan

Rim Sim: A Role-Play Simulation: USGS Bulletin 2212 (in English, Spanish, and Chinese)

Perspectives on Energy: Today and Tomorrow-Discussions of resources, technology, economics and policy: 2-DVD set available from the AAPG and AGI online bookstores. For more information on this product visit the Our Projects page at http://www.circum-pacificcouncil.org

\section{Circum-Pacific Map Project}

The Circum-Pacific Map Project (CPMP) is a cooperative international effort to assemble and publish new geographic, geological, geophysical and resource maps of the Pacific Basin and surrounding continental areas. CPMP initially focused on compiling geologic, tectonic, and resource data, subsequently was broadened to include geohazard and environmental information and extended to cover Arctic and Antarctic regions. The Circum-Pacific Map Project was organized under six panels of volunteer international scientists who lived or worked in the area of study. New information was assembled by the Regional Panels and submitted in draft format to the Map Project staff at the USGS for further compilation and preparation of printers-copy. Western North America and Adjacent Ocean Basins-Beaufort

The Circum-Pacific Maps are intended to aid in the exploration for new resources and to stimulate research in all aspects of the earth sciences and natural resources of the region. Fifty-one maps that show the relationship of known energy and mineral resources to geology, tectonics, crustal dynamics, and natural hazards have been published. Two geographic series and seven thematic series are plotted on six sheets at a scale of 1:10 million representing four overlapping Pacific Basin quadrants and both polar regions. Some of these series are also compiled on a Pacific Basin map at a scale of 1:17 million. Since 1990, the Circum-Pacific Map Series has been printed and distributed in collaboration with the U.S. Geological Survey. Although many of the older maps are now out of print, sixteen recently published maps are available from the USGS and some older series are available from the CPCEMR. Circum Pacific maps are available at: http://www.circum-pacificcouncil.org.

\section{East Asia Geographic Map Series}

In cooperation with the USGS and the Coordinating Committee for Geoscience Programmes in East and Southeast Asia (CCOP) a series of eight overlapping 1:2 million sheets useful for the compilation and display of geoscience resource and environmental information have been published:
1. Japan, Korea, Northeast China
2. Southeast China
3. Southeast Asia Islands
4. Philippines
5. Malaysia, Indonesia (West)
6. Indonesia (East)
7. Papua New Guinea, Solomon
8. Western Pacific Islands

\section{Circum-Pacific Geospatial Data Project}

In cooperation with the USGS and CCOP, and with financial support from the Industrial Associates, a digital geoscience databank including a lexicon of geologic names and a compilation of bio- and chronostratigraphic data for southeast Asia.

\section{Crowding the Rim}

The Pacific Rim region is currently experiencing unprecedented population and infrastructure growth. With international economic and social connections increasing, the consequences of a disaster in any one place may reverberate throughout the Rim. In May 2000, the Crowding the Rim (CTR) Initiative established a partnership among the American Red Cross, Circum-Pacific Council, Stanford University and the United States Geological Survey to understand the increasing potential for catastrophic social and economic disasters. The Crowding the Rim Project creates tools to promote cross-sector international discussion to mitigate regional catastrophes. Visit: http://www.crowdingtherim.org

HazPac, short for hazards of the Pacific is a

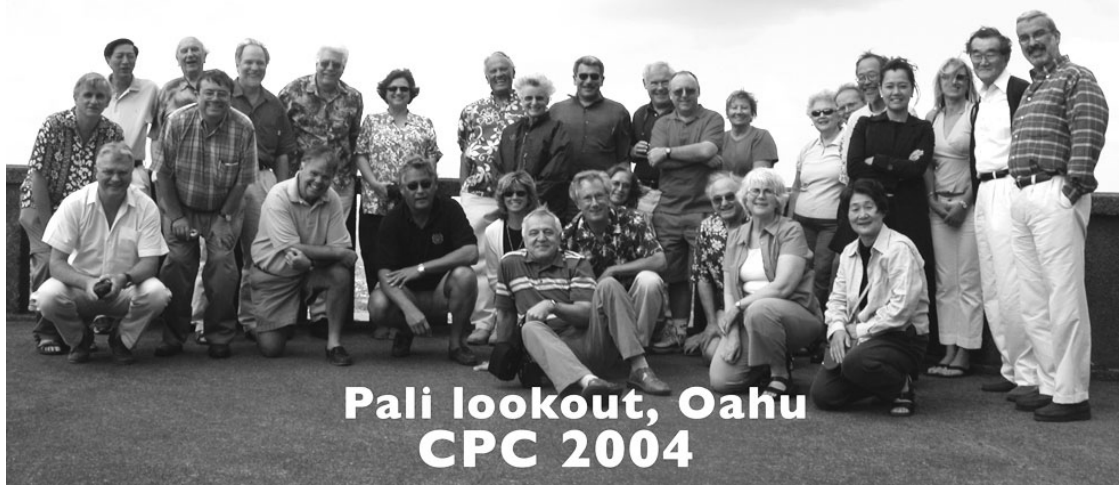
compilation of digital data on natural hazards, population and infrastructure. Utilizing GIS technology, one can view and query the HazPac dataset to discover the regional interconnections and shared risks of the Pacific Rim region. This dataset is available on CD-ROM from the USGS or can be down loaded for free from the website, http://www.hazpac.org .

RimSim, short for Pacific Rim Simulation is a conflict negotiation simulation that provides an opportunity to address risk in an increasingly interconnected global community. Participants are introduced to a collaborative problem-solving approach that emphasizes face-to-face dialogue and multinational cooperation in dealing with humanitarian con-

A group picture of CPC directors who attended CPC Directors meeting at the East West Center in Hawaii. cerns as well as long-term efforts to reconstruct local and regional infrastructure. Workshops featuring 
RimSim have been held in Palo Alto, USA; San Jose, Costa Rica; Shanghai, China; and Bangkok, Thailand.

The CTR Educational Module, a set of secondary-level classroom curricula, was developed to educate young people and others about risk in the context of the Pacific Rim. These teacher-friendly lesson plans and exercises incorporate group discussions, collaborative problem solving and Geographic Information Systems (GIS) technology. This module was published by the Stanford Program on International and Cross-Cultural Education (SPICE).

New Initiatives: Addressing the needs of local populations in the Circum-Pacific Region

Tsunamis - the waves that destroy: Tsunamis may be locally generated or they may travel at high speeds across an entire ocean. The project is designed to work with the Civil Defense and local authorities of coastal zones around the pacific margin. Outcome objectives include better education, improved warning systems, enhanced responders capability and more prudent land use planning.

Geothermics - an energy source not yet fully realized: The goal of this project is to develop a workshop curriculum designed to highlight how and where small supplies of geothermal energy can have significant impact on selected local areas. The intent is to broaden the application of geothermics.

Aggregates - the building blocks of infrastructure: The availability of materials and the environmental impacts of extraction are critical issues for a number Pacific rim countries. The CPCEMR wishes to elevate this local issue to international status and develop a methodology for conflict resolution among the construction industry, city governments, environmentalists, and the recreation community.

Powering the Rim - the future of energy security in the Circum-Pacific region. Although much is known about the distribution of energy resources throughout the Pacific Rim, no synthesis of this information exists to aid decision-makers in evaluating geopolitical risks and opportunities associated with energy resource production, transportation, and consumption in this region. The CPCEMR proposes to develop, compile, and present the fundamental energy resource data necessary to make well-informed, strategic energy policy decisions for the Pacific Rim. These data will include estimates of reserves and resources of fossil fuels, including oil, natural gas, and coal; sources of renewable energy production and potential, including geothermal, wind, solar, and biomass; and strategic minerals such as uranium. The occurrence of these energy resources combined with consumption data and projected demand will provide a graphic representation of where energy resources can be produced, where they are used and where they will be needed in the next two decades. We propose to create an energy resource atlas designed to illustrate these critical relationships.

\section{Circum-Pacific Council relationship to IUGS}

Like the IUGS, the Circum-Pacific Council is an international organization dedicated to the geological sciences. The Council actively seeks to partner with the IUGS and other organizations for scientific interchange and research. The Council through these collaborations strives to foster better understanding and communication for sustaining earth resources and understanding risk in the Pacific Region.

\section{Circum-Pacific Operational and Financial Support}

Operational support for CPCEMR activities is largely by volunteers and "in kind" support by partners and cosponsoring organizations. Financial support for projects such as CTR is provide by bequests and grants. Recent sponsors include the following:

IUGS

David and Lucile Packard Foundation

ChevronTexaco Inc.

British Petroleum Company

Thales GeoSolutions (Pacific), Inc.

Pacific Disaster Center

\section{Circum-Pacific Council}

Secretariat:

Nancy Zeigler

12201 Sunrise Valley Drive, MS-917

Reston, VA 20192, U.S.A.

Tel: (703) 648-4227

Fax: (703) 648-4227

E-mail: nzeigler@usgs.gov

Executive Office:

345 Middlefield Rd. MS-973

Menlo Park, CA 94025, U.S.A.

Tel: (650) 329-5122 (5430)

Fax: (650) 329-4936

\section{CPCEMR Executive Officers}

Nahum Schneidermann, Chairman E-mail: NAHU@chevrontexaco.com

David G. Howell, President

E-mail: dhowell@usgs.gov

George Gryc, Treasurer

E-mail: ggryc@usgs.gov

Edward Saade, Secretary

E-mail: esaade@fugro.com

P. Patrick Leahy, V.P. North America

E-mail: pleahy@usgs.gov

Giovanni Rosania, V.P. Latin America

E-mail:nino90cm@zona-andina.net

Robin Falconer, V.P. Oceania

E-mail: r.falconer@gns.cri.nz

Chen Shick Pei, V.P. Asia

E-mail: spchen@ccop.or.th

David G. Howell

U. S. Geological Survey M/S 973

345 Middlefield Rd.

Menlo Park, CA 94025

USA

Tex: $650329-5430$

Fax: 650-329-4636

E-mail:dhowell@usge.gov 